\begin{tabular}{|c|c|c|c|c|c|c|}
\hline Impact Factor: & $\begin{array}{l}\text { ISRA (India) } \\
\text { ISI (Dubai, UAE } \\
\text { GIF (Australia) } \\
\text { JIF }\end{array}$ & $\begin{array}{r}=1.344 \\
=0.829 \\
=0.564 \\
=1.500\end{array}$ & $\begin{array}{l}\text { SIS (USA) } \\
\text { PИНЦ (Russia } \\
\text { ESJI (KZ) } \\
\text { SJIF (Morocco }\end{array}$ & $\begin{array}{l}=0.912 \\
=0.234 \\
=\mathbf{1 . 0 4 2} \\
=\mathbf{2 . 0 3 1}\end{array}$ & $\begin{array}{l}\text { ICV (Poland) } \\
\text { PIF (India) } \\
\text { IBI (India) }\end{array}$ & $\begin{array}{l}=6.630 \\
=1.940 \\
=4.260\end{array}$ \\
\hline
\end{tabular}

\section{International Scientific Journal Theoretical \& Applied Science}

p-ISSN: 2308-4944 (print) e-ISSN: 2409-0085 (online)

Year: $2016 \quad$ Issue: 9 Volume: 41

Published: $30.09 .2016 \quad$ http://T-Science.org

SECTION 31. Economic research, finance, innovation, risk management.
Nurserik Zhakipbekovich Nurzhanov Muster student of Kazakh Engineering and Pedagogical University of Nations Friendship

Aigul Kuanyshevna Kupesheva Candidate of economical science Chief of department of Kazakh Engineering and Pedagogical University of Nations Friendship

Ersultan Zhomartovich Shalkhar Muster student of Kazakh Engineering and Pedagogical University of Nations Friendship

Nurlan Muhtarovich Batyrbaev Candidate of law science, professor Vice president of International Kazakh-

Turkish University after H.A.Yessevi

Erkin Shazhievich Dusipov

Doctor of law science, professor Zhetysu state University after I.Zhansugurov

Yernar Sailaubekovich Shalkharov Master of law, economics, bachelor of biology Corresponding member of Theoretical and Applied Science Academy. General director of BeinAgroIndustries LTD yernar_shalkharov@bk.ru

\title{
THEORETICAL BASIS OF COORDINATIONAL RESULTS BETWEEN SCIENCE, BUSINESS AND STATE ACCORDING TO CONDITIONS OF INNOVATIONAL INFLUENCE OF NATIONAL ECONOMICS
}

\footnotetext{
Abstract: Nowadays, the impact of science, business and government reforms have a greater and greater impact on the national economy. So, as one of the Equilibrium of all three means of contact can be called scientific grants for the development of a product in the target area of market relations. At the same time such funding may be allocated by both the state and commercial organizations. Most often, the present is relevant in the field of agriculture and industry in general.

Key words: social grants, audit services, scientific evidence, equilibrium, business, reforms, chief governmental body, accounting procedure.

Language: English

Citation: Nurzhanov NZ, Kupesheva AK, Shalkhar EZ, Batyrbaev NM, Dusipov ES, Shalkharov YS (2016) THEORETICAL BASIS OF COORDINATIONAL RESULTS BETWEEN SCIENCE, BUSINESS AND STATE ACCORDING TO CONDITIONS OF INNOVATIONAL INFLUENCE OF NATIONAL ECONOMICS. ISJ Theoretical \& Applied Science, 09 (41): 149-152.

Soi: http://s-o-i.org/1.1/TAS-09-41-24 Doi: crossef http://dx.doi.org/10.15863/TAS.2016.09.41.24
}

\section{Introduction}

The main argument in favor of studying all the theoretical foundations of the economy is that the economy explores issues that relate to all people without exception. All people involved in the sphere of economic life (they work, earn an income, make purchases, pay taxes, etc.). Every person will sooner or later ask the question: what determines the salary, why prices are rising, why in one country the standard of living is higher than in another, it is more 


\begin{tabular}{|c|c|c|c|c|c|c|}
\hline Impact Factor: & $\begin{array}{l}\text { ISRA (India) } \\
\text { ISI (Dubai, UAF } \\
\text { GIF (Australia) } \\
\text { JIF }\end{array}$ & $\begin{array}{l}=1.344 \\
=0.829 \\
=0.564 \\
=1.500\end{array}$ & $\begin{array}{l}\text { SIS (USA) } \\
\text { PИНЦ (Russia } \\
\text { ESJI (KZ) } \\
\text { SJIF (Morocco }\end{array}$ & $\begin{array}{l}=0.912 \\
=0.234 \\
=\mathbf{1 . 0 4 2} \\
=\mathbf{2 . 0 3 1}\end{array}$ & $\begin{array}{l}\text { ICV (Poland) } \\
\text { PIF (India) } \\
\text { IBI (India) }\end{array}$ & $\begin{array}{l}=6.630 \\
=1.940 \\
=4.260\end{array}$ \\
\hline
\end{tabular}

profitable - to be employed or to organize their own business, put money in the bank or buy shares, and in general, what is money? [1].

\section{Materials and Methods}

Since a systematic course of study, you must first find out what the economy is that it examines what its functions are, what methods used by economists in the analysis of economic relationships and regularities.

The word "economy" of Greek origin (oikos agriculture, nomos - law), it means "the laws of economic management." Today, the term "economy" is used in two main senses: firstly, as a synonym for the word "economy" (the economy of the country, region, enterprise, planned, market economy, etc.) and, secondly, as the name of science that studies the theoretical foundations of management [2].

Like any science, the economy performs primarily cognitive function - it theoretically explains how the economy, the essence, causes, effects of economic processes (such as banks make money, what is the essence of inflation, as the proposal affects the price, etc. ). On the basis of theoretical generalizations actual facts of economic life economy explains that there is or can be, formulates principles of economic behavior (positive economics) [3]

Economic policy should not be voluntarist (willed), it must build on the achievements of economic theory. For example, if you know that there is an inverse relationship, the respective legislative bodies, governments in their practical activities aimed at reducing the unemployment rate, should be taken into account is the position between the level of unemployment and the rate of price increases [4].

Depending on the object of study the economy can be subdivided into two major parts:

Microeconomics - part of economics that examines the behavior of individual economic entities - customers, firms, analyzes the mechanisms of functioning of individual markets, the allocation of resources in the directions of their use, income generation, etc.

Macroeconomics - a part of economics that studies the functioning of the economy as a whole such common phenomena and processes as the growth rate of national output, inflation, unemployment, budget deficits, public debt, state regulation methods, etc [5].

Despite differences in emphasis at the microand macro-analysis used the same concepts and theories are considered the same problem.
Economy - social science. It examines certain aspects of society and as such is closely related to other social sciences: history, sociology, political science, psychology, law, etc. Contact economics and law is due to the fact that the economic life of society, economic and legal relations are closely intertwined [6].

The economy can not function properly without an appropriate legal framework - set of rules governing the activities of economic entities both at micro and macro level. At the same time the need for appropriate legal norms generated by changes in the economic life of society, Speaking about the relationship of the economy and other sciences, it should be noted that the economy - the most accurate of all the social sciences, so it makes wide use of mathematical tools, quantitative research methods [7].

Considering such things as price, profit, interest, demand, etc., along with economists always use quality and quantitative analysis.

Studying the functioning of the economy and pushing the mechanism requirements, the results of this operation, the economy as a science uses some research methods (method - is the path way to the study of an object). How the economy is exploring his subject? [8].

The method of scientific abstraction. Its essence - the cleansing of the test subject from the private, accidental, transitory, and the allocation of essential, permanent, typical. The result of abstraction - the categories, concepts, expressing the essential aspects of the objects (price, profit, rent, etc.), and economic laws (principles), reflecting the permanent, stable, recurring causal relationships between economic phenomena (the law of demand: price increase (cause) leads to lower demand (a consequence)).

The economy is widely used functional analysis [9].

Economic modeling today - a very common method for the study of economic problems. Models are simplified, formalized description of economic reality, they are ignoring the many minor details that complicate the analysis of various interdependencies, allow to better understand and describe the reasons for the relationship, the laws, the consequences of certain economic processes and phenomena [10].

Mathematical modeling is difficult enough in the economy, as the economy - a multi-dimensional system, the functioning and development of which is largely stochastic (probabilistic) character is influenced by many external factors, 


\begin{tabular}{|c|c|c|c|c|c|c|}
\hline Impact Factor: & $\begin{array}{l}\text { ISRA (India) } \\
\text { ISI (Dubai, UAF } \\
\text { GIF (Australia) } \\
\text { JIF }\end{array}$ & $\begin{array}{l}=1.344 \\
=0.829 \\
=0.564 \\
=1.500\end{array}$ & $\begin{array}{l}\text { SIS (USA) } \\
\text { PИНЦ (Russia } \\
\text { ESJI (KZ) } \\
\text { SJIF (Morocco }\end{array}$ & $\begin{array}{l}=0.912 \\
=0.234 \\
=\mathbf{1 . 0 4 2} \\
=\mathbf{2 . 0 3 1}\end{array}$ & $\begin{array}{l}\text { ICV (Poland) } \\
\text { PIF (India) } \\
\text { IBI (India) }\end{array}$ & $\begin{array}{l}=6.630 \\
=1.940 \\
=4.260\end{array}$ \\
\hline
\end{tabular}

Economists in their studies often use assumed "ceteris paribus", ie It assumes that all other variables, except for those that are currently investigated are unchanged. This method simplifies the process of analyzing the study of communication [11].

Economic experiments - an artificial reproduction of economic phenomena in certain circumstances, for the purpose of study and further practical changes. Experimentation as a learning method can be carried out both at the micro and at the macro level. However, experiments have not forcibly break the natural economic processes, to squeeze the real economic life in the framework of artificial structures [12].

Whatever method is used by economists in their research, practice, the economic reality is the criterion of faithfulness of those or other conclusions, the provisions of the economic theory. If we can say that "this is true in theory but not in practice", which means that it is not true or that theoretical proposition, this or that conclusion [13].

Efficiency in distribution. The question of "for whom?" Is directly related to efficiency. The distribution of any given amount of good can be improved through the exchange, in which the preferences of several people will be satisfied more fully. As long as the possible exchange of existing goods, so that some people may satisfy their desires without harming others, the effectiveness of the distribution can be improved, even if the total amount of wealth remains the same [14].

\section{Conclusion}

Fairness in the distribution. In practice, the question of justice is often dominates the efficiency in the allocation of the discussions. According to the concept of equality, all the people, by the very fact of belonging to humanity, deserve to receive a portion of the goods and services produced by the economy. There are many variations of this theory. Some believe that all the income and wealth should be shared equally. Others believe that people have a right to the "minimum necessary" income level, but that any excess above this level [15].

\section{Background.}

For a whole competent it is actual to notice that all issues in articles were formulated from the surveys of BeinAgroIndustries LTD. Also, it is important to mention together work of two university staff: Kazakh Engineering and Pedagogical University of Nations Friendship and International Kazakh-Turkish University after Khoga Akhmet Yassavi. In case of novelty, p.t.value the main author is the last in the list of authors.

\section{References:}

1. Dušan Marković, Dalibor Petković, Vlastimir Nikolić, Miloš Milovančević, Biljana Petković (2016) Soft computing prediction of economic growth based in science and technology factors. Original Research Article. Physica A: Statistical Mechanics and its Applications, Volume 465, 1 January 2016, Pages 217-220.

2. Evgeny Kolbachev, Tatiana Kolbacheva, Yuliya Salnikova (2015) Application of Natural Science and Engineering Methods as a Trend in the Development of Economic and Management Research and Education. Original Research Article. Procedia - Social and Behavioral Sciences, Volume 214, 5 December 2015, Pages 1000-1007.

3. Till Düppe (2015) Border cases between autonomy and relevance: Economic sciences in Berlin-A natural experiment. Original
Research Article. Studies in History and Philosophy of Science Part A, Volume 51, June 2015, Pages 22-32.

4. Ömer Acar, Ayşe Büber, Zehra Tola (2015) The Effect of Gender and Socioeconomic Status of Students on Their Physics Conceptual Knowledge, Scientific Reasoning, and Nature of Science Understanding. Original Research Article. Procedia - Social and Behavioral Sciences, Volume 174, 12 February 2015, Pages 2753-2756.

5. Maria Rosaria Carillo, Erasmo Papagni (2014) "Little Science" and "Big Science": The institution of "Open Science" as a cause of scientific and economic inequalities among countries. Original Research Article. Economic Modelling, Volume 43, December 2014, Pages 42-56. 


\begin{tabular}{l|lrl|l|ll} 
& ISRA (India) & $=\mathbf{1 . 3 4 4}$ & SIS (USA) & $=\mathbf{0 . 9 1 2}$ & ICV (Poland) & $=\mathbf{6 . 6 3 0}$ \\
Impact Factor: & ISI (Dubai, UAE) $=\mathbf{0 . 8 2 9}$ & PUHL (Russia) $=\mathbf{0 . 2 3 4}$ & PIF (India) & $=\mathbf{1 . 9 4 0}$ \\
& GIF (Australia) & $\mathbf{0 . 5 6 4}$ & ESJI (KZ) & $=\mathbf{1 . 0 4 2}$ & IBI (India) & $=\mathbf{4 . 2 6 0}$ \\
& JIF & $\mathbf{1 . 5 0 0}$ & SJIF (Morocco) & $=\mathbf{2 . 0 3 1}$ & & \\
\hline
\end{tabular}

6. Darla K. Munroe, Kendra McSweeney, Jeffrey L. Olson, Becky Mansfield (2014) Using economic geography to reinvigorate landchange science. Original Research Article. Geoforum, Volume 52, March 2014, Pages 1221.

7. D.J. Vicente, L. Rodríguez-Sinobas, L. Garrote, R. Sánchez (2016) Application of the system of environmental economic accounting for water SEEAW to the Spanish part of the Duero basin: Lessons learned. Original Research Article. Science of The Total Environment, Volumes 563-564, 1 September 2016, Pages 611-622.

8. Soyeon Yi, Hyun-Jin Jang, Hyo Suk Lee, JongPhil Yu, Soyeon Kim, Joohee Lee, Hee-Young Hur (2013) Economic value analysis of the return from the Korean astronaut program and the science culture diffusion activity in Korea. Original Research Article. Acta Astronautica, Volume 87, June-July 2013, Pages 1-7.

9. Teijo Rytteri, Taru Peltola, Leena A. Leskinen (2016) Co-production of forestry science and society: Evolving interpretations of economic sustainability in Finnish forestry textbooks. Original Research Article. Journal of Forest Economics, Volume 24, August 2016, Pages 21-36.

10. Theresa Sult, Véronique J. Barthet, Laurie Bennett, Alison Edwards, Brandon Fast, Nancy Gillikin, Karen Launis, Stephen New, Kristina Rogers-Szuma, Jane Sabbatini, Jannavi R. Srinivasan, Gregory B. Tilton, T.V. Venkatesh (2016) Report: Release of the International Life Sciences Institute Crop Composition Database Version 5. Journal of Food
Composition and Analysis, Volume 51, August 2016, Pages 106-111.

11. Wang Licheng (2011) Science \& Technology Input and Economic Growth: An Empirical Analysis Based on the Three Major Coastal Economic Regions of China. Original Research Article. Energy Procedia, Volume 5, 2011, Pages 1779-1783.

12. Mark W. Brunson, Lynn Huntsinger, Urs P. Kreuter, John P. Ritten (2016) Usable SocioEconomic Science for Rangelands. Original Research Article. Rangelands, Volume 38, Issue 2, April 2016, Pages 85-89.

13. Aurora A.C. Teixeira, Anabela S.S. Queirós (2016) Economic growth, human capital and structural change: A dynamic panel data analysis. Original Research Article. Research Policy, Volume 45, Issue 8, October 2016, Pages 1636-1648.

14. Fung-Wei Chang, Wen-Ying Lee, Yueh-Ping Liu, Jing-Jung Yang, Shu-Pin Chen, KuanChen Cheng, Yan-Cen Lin, Te-Wei Ho, FengHsiang Chiu, Ren-Jun Hsu, Jui-Ming Liu (2016) The relationship between economic conditions and postpartum depression in Taiwan: a nationwide population-based study. Original Research Article. Journal of Affective Disorders, Volume 204, 1 November 2016, Pages 174-179.

15. Simangaliso Chitunhu, Eustasius Musenge. (2016) Spatial and socio-economic effects on malaria morbidity in children under 5 years in Malawi in 2012. Original Research Article. Spatial and Spatio-temporal Epidemiology, Volume 16, February 2016, Pages 21-33. 